\title{
Malignant Sinonasal Tumors: Update on Histological and Clinical Management
}

\author{
Alessandra Bracigliano ${ }^{1, *}$, Fabiana Tatangelo ${ }^{2} \mathbb{D}$, Francesco Perri ${ }^{3} \mathbb{D}$, Giuseppe Di Lorenzo ${ }^{4}\left(\mathbb{D}\right.$, Roberto Tafuto $^{5}$, \\ Alessandro Ottaiano ${ }^{6}\left(\mathbb{D}\right.$, Ottavia Clemente ${ }^{4}$, Maria Luisa Barretta ${ }^{7}$, Nunzia Simona Losito ${ }^{2}$, \\ Mariachiara Santorsola ${ }^{6}$ and Salvatore Tafuto ${ }^{4}$ (iD)
}

1 Nuclear Medicine Unit, Istituto Nazionale Tumori, IRCCS—Fondazione “G. Pascale”, 80131 Naples, Italy

2 Department of Pathology, Istituto Nazionale Tumori, IRCCS—Fondazione "G. Pascale", 80131 Naples, Italy; f.tatangelo@istitutotumori.na.it (F.T.); n.losito@istitutotumori.na.it (N.S.L.)

3 Head and Neck Oncology Unit, Istituto Nazionale Tumori, IRCCS—Fondazione "G. Pascale", 80131 Naples, Italy; f.perri@istitutotumori.na.it

4 Sarcomas and Rare Tumors Unit, Istituto Nazionale Tumori, IRCCS—Fondazione "G. Pascale", 80131 Naples, Italy; giuseppedilorenzo10@gmail.com (G.D.L.); ottavia.clemente@istitutotumori.na.it (O.C.); s.tafuto@istitutotumori.na.it (S.T.)

5 Neurosurgery Unit, Federico II University, 80131 Naples, Italy; rob.tafuto@gmail.com

6 Division of Innovative Therapies for Abdominal Metastases, Istituto Nazionale Tumori, IRCCS—Fondazione "G. Pascale", 80131 Naples, Italy; a.ottaiano@istitutotumori.na.it (A.O.); mariachiara.santorsola@istitutotumori.na.it (M.S.)

7 Radiology Unit, Istituto Nazionale Tumori, IRCCS—Fondazione “G. Pascale”, 80131 Naples, Italy; m.barretta@istitutotumori.na.it

* Correspondence: a.bracigliano@istitutotumori.na.it

Citation: Bracigliano, A.;

Tatangelo, F.; Perri, F.; Di Lorenzo, G.;

Tafuto, R.; Ottaiano, A.; Clemente, O.;

Barretta, M.L.; Losito, N.S.;

Santorsola, M.; et al. Malignant

Sinonasal Tumors: Update on

Histological and Clinical

Management. Curr. Oncol. 2021, 28,

2420-2438. https://doi.org/10.3390/ curroncol28040222

Received: 26 April 2021

Accepted: 29 June 2021

Published: 1 July 2021

Publisher's Note: MDPI stays neutral with regard to jurisdictional claims in published maps and institutional affiliations.

\begin{abstract}
Tumors of nasal cavity and paranasal sinuses (TuNSs) are rare and heterogeneous malignancies, presenting different histological features and clinical behavior. We reviewed the literature about etiology, biology, and clinical features of TuNSs to define pathologic features and possible treatment strategies. From a diagnostic point of view, it is mandatory to have high expertise and perform an immunohistochemical assessment to distinguish between different histotypes. Due to the extreme rarity of these neoplasms, there are no standard and evidence-based therapeutic strategies, lacking prospective and large clinical trials. In fact, most studies are retrospective analyses. Surgery represents the mainstay of treatment of TuNSs for small and localized tumors allowing complete tumor removal. Locally advanced lesions require more demolitive surgery that should be always followed by adjuvant radio- or chemo-radiotherapy. Recurrent/metastatic disease requires palliative chemo- and/or radiotherapy. Many studies emphasize the role of specific genes mutations in the development of TuNSs like mutations in the exons 4-9 of the TP53 gene, in the exon 9 of the PIK3CA gene and in the promoter of the TERT gene. In the near future, this genetic assessment will have new therapeutic implications. Future improvements in the understanding of the etiology, biology, and clinical features of TuNSs are warranted to improve their management.
\end{abstract}

Keywords: sinonasal neuroendocrine neoplasms; tumors of sinonasal tract; ethmoid sinus salivary gland type; neuroendocrine carcinomas of the head and neck

\section{Introduction}

Sinonasal tumors (TuNSs) are a rare disease affecting fewer than 1 person out of 100,000 individuals per year worldwide. They account for less than $1 \%$ of all human malignant cancers, less than $3 \%$ of all head and neck carcinomas, and have a peak incidence in the 5 th to 7 th decades with a male preponderance (2:1 rate) [1-6]. TuNSs can have an epithelial (carcinomas) or mesenchymal (sarcomas) origin. In fact, substrates for their development can be the different tissues covering nasal cavities and paranasal sinuses, such as mucosal epithelium, serous gland epithelium, mesenchymal tissues, cartilage, 
neural/neuroectodermal tissues, hemato-lymphoid cells, and the odontogenic apparatus. Epithelial tumors are the most common form and originate from the epithelial lining, accessory salivary glands, neuroendocrine tissue, and olfactory epithelium. Conversely, mesenchymal tumors derive from the supporting tissue [7].

TuNSs are a heterogeneous category of malignancies, presenting both different histological features and clinical behavior. They should not be included in the "miscellany" of head and neck cancers, but considered as separate entities. The prognosis is dismal with a 5-year overall survival ranging from $60 \%$ for early tumors (T1-2) to $20 \%$ for advanced disease. Most newly diagnosed TuNSs are locally advanced or metastatic cancers, not suitable for radical treatments. Surgery represents the mainstay of treatment and every patient with a diagnosis of TuNSs, independently from their histology, should be evaluated by a surgeon in the context of a multidisciplinary team [8]. Unresectable tumors present a poor outcome and they are treated with palliative strategies. Understanding the etiology, biology, and clinical features of TuNSs may help the specialists to face them, since no clear treatment guidelines are available. In sinonasal imaging, it is well known that benign tumours cause slight remodeling and thickening of adjacent bone, while malignant ones destroy it. However, malignant tumours may also remodel bone rather than destroy it; e.g., sinonasal sarcomas, minor salivary gland carcinomas, extramedullary plasmacytomas, large cell lymphomas, olfactory neuroblastomas, and hemangiopericytomas. In clinical practice, the most frequent five histotypes of TuNSs include squamous cell carcinoma, lymphoepithelial carcinoma, undifferentiated nasal-sinus carcinoma (SNUC), adenocarcinomas, and neuroendocrine tumors. They present with different pathologic appearance and clinical behavior (5-year survival varies from 22 to $67 \%$ ). Currently, scientific efforts are oriented to gaining better knowledge of the tumorigenic pathways and to defining alternative treatment strategies.

\section{Materials and Methods}

We made a literature review on TuNSs using a web-based search on Pubmed Central, Scopus, Google Scholar, and Cochrane Library. The search terms used to guide the research were: "paranasal sinus and nasal cavity cancers", "paranasal sinus cancer genetics", "paranasal sinus cancer diagnosis", "standard treatments for paranasal sinus cancer", and "histological variants".

\section{Etiopathogenesis of TuNSs}

Occupational exposure to wood dust, leather, flour, tissue, and other industrial compounds (chromium and nickel), exposure to glues, formaldehyde, and organic solvents are shown to have a causal role in the development of TuNSs in several studies. For this reason, TuNSs are officially recognized as "occupational diseases" [9-15]. Additional non-occupational risk factors for TuNSs development include tobacco, nasal polyposis, inverted sinusal papilloma [16,17], chronic sinusitis and, finally, radiotherapy used for the treatment of retinoblastoma, a hereditary eye tumor that generally affects children. Evidence from literature suggests that also smoking tobacco can increase the risk of sinonasal tumors $[15,18,19]$ and, in particular, of the squamous cell subtype (SNSCC) [19-21]. A report [19] showed a significant increase in the risk of developing TuNSs in patients exposed to wood dust with an odds ratio (OR) of 1.72 (CI 95\%: 1.16-2.56) adjusted for many relevant risk factors, including tobacco smoking. Furthermore, human papillomavirus (HPV) has been detected in about $30 \%$ of sinonasal carcinomas and high-risk HPV 16 seems to be most frequently associated with the squamous cell histotype [21]. The identification of $\mathrm{HPV}$ in sinonasal carcinomas has important clinical implications, since it is associated with a favorable prognosis [21-25]. Only a few scientific works demonstrated that benign nasal diseases may represent an additional risk for the development of nasal cavity/paranasal sinus (NCPS) or nasopharyngeal cancers, but these data need to be confirmed [26-29] (Table 1). 
Table 1. Sinonasal carcinoma risk factors.

\begin{tabular}{lll}
\hline \multicolumn{1}{c}{ Major Risk Factors } & \multicolumn{1}{c}{ Minor Risk Factors } \\
\hline - $\quad \begin{array}{l}\text { inhalation of dust produced during the } \\
\text { processing of wood, leather, flour, textiles, } \\
\text { or nickel and chromium dust; } \\
\text { cigarette smoke. }\end{array}$ & - & $\begin{array}{l}\text { Human papillomavirus infections; } \\
\text { Radiotherapy carried out for the } \\
\text { treatment of retinoblastoma; } \\
\text { Glue, formaldehyde, organic } \\
\text { solvents, etc. }\end{array}$ \\
\hline
\end{tabular}

\section{Pathological Classification and Histotypes}

The 2012 World Health Organization (WHO) classification system divided TuNSs into different histological categories based on the site of origin and their clinical behavior [30] with 5 -year overall survival ranging from $22 \%$ to $67 \%$. TuNSs include a great variety of histologic subtypes. They can be subdivided into squamous cell carcinomas, lymphoepithelial carcinoma, neuroendocrine carcinomas or undifferentiated sinonasal carcinomas (SNUC), adenocarcinomas intestinal-type (ITAC) and not intestinal-type (NON-ITAC), adenocarcinomas salivary-type, neuroendocrine tumors (NENS), and more rarely, adenoid cystic carcinomas and olfactory neuroblastomas (esthesioneuroblastomas) [3-6] (Table 2).

Table 2. Sinonasal neuroendocrine tumor classification.

\begin{tabular}{|c|c|c|}
\hline & Malignant Epithelial Tumors & Benign Epithelial Tumors \\
\hline$\bullet$ & Squamous cell carcinoma & - Sinonasal papillomas \\
\hline$\bigcirc$ & Verrucous carcinoma & $\bigcirc \quad$ Inverted papilloma \\
\hline 0 & Papillary squamous cell carcinoma & (Schneiderian papilloma, inverted type) \\
\hline 0 & Basaloid squamous cell carcinoma & Oncocytic papilloma \\
\hline$\bigcirc$ & Spindle cell carcinoma & (Schneiderian papilloma, oncocytic type) \\
\hline ○ & Adenosquamous carcinoma & Exophytic papilloma \\
\hline$\bigcirc$ & Acantholytic squamous cell carcinoma & (Schneiderian papilloma, exophytic type) \\
\hline$\bullet$ & Lymphoepithelial carcinoma & - $\quad$ Salivary gland-type adenomas \\
\hline • & Sinonasal undifferentiated carcinoma & Pleomorphic adenoma \\
\hline$\bullet$ & Adenocarcinoma & Myoepithelioma \\
\hline ○ & Intestinal-type adenocarcinoma & Oncocytoma \\
\hline 0 & Nonintestinal-type adenocarcinoma & \\
\hline$\bullet$ & Salivary gland-type carcinomas & \\
\hline ○ & Adenoid cystic carcinoma & \\
\hline O & Acinic cell carcinoma & \\
\hline
\end{tabular}


Table 2. Cont.

\section{Malignant Epithelial Tumors}

- Mucoepidermoid carcinoma

Epithelial-myoepithelial carcinoma

- Clear cell carcinoma N.O.S.

- Myoepithelial carcinoma

- Carcinoma ex pleomorphic adenoma

Polymorphous low-grade adenocarcinoma

- Neuroendocrine tumors

○ Typical carcinoid

Atypical carcinoid

Small cell carcinoma, neuroendocrine type

Soft tissue tumors

Tumors of bone and cartilage

- Malignant tumors

- Malignant tumors

Fibrosarcoma

Chondrosarcoma

- Malignant fibrous histiocytoma

- Mesenchymal chondrosarcoma

Leiomyosarcoma

Osteosarcoma

Rhabdomyosarcoma

- Chordoma

○ Angiosarcoma

Malignant peripheral nerve sheath tumor

- $\quad$ Borderline and low malignant potential tumors

- $\quad$ Benign tumors

Giant cell lesion

Giant cell tumor

Desmoid-type fibromatosis

$\bigcirc \quad$ Chondroma

Inflammatory myofibroblastic tumor

Osteoma

Glomangiopericytoma

Chondroblastoma

(Sinonasal-type haemangiopericytoma)

- Chondromyxoid fibroma

Extrapleural solitary fibrous tumor

Osteochondroma (exostosis) 
Table 2. Cont.

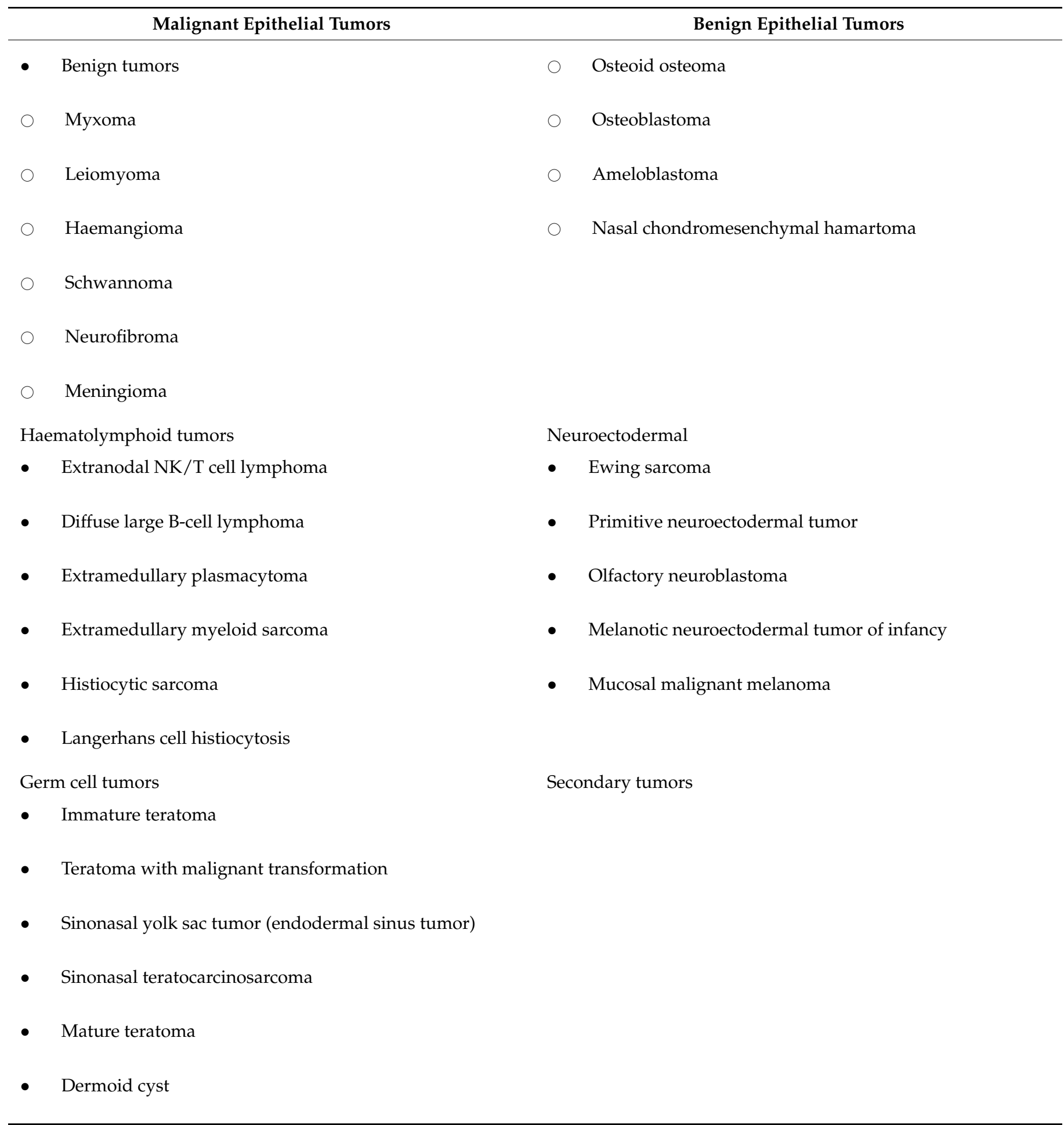

\subsection{Squamous Cell Carcinoma}

Squamous cell carcinoma is the most common form of TuNSs (3\%) [10,15]. It is divided into keratinizing and non-keratinizing subtypes and generally arises from the maxillary sinus and nasal cavity. Squamous cell carcinoma is associated to arsenic and welding fumes exposure and it often affects male adult subjects with a male:female ratio of 2:1 [31-33]. The keratinizing carcinoma does not differ from the squamocellular forms that arise at the mucous level of other head/neck sites. Recently, a possible correlation has emerged 
between some sinonasal squamous cell carcinomas and high-risk HPV infection (about 30\% of cases) $[24-28,34,35]$. Other rare variants of squamous cell carcinoma of the nasal cavities and paranasal sinuses are papillary cancer, basaloid carcinoma, sarcomatoid carcinoma, adenosquamous carcinoma, and acantholytic cancer. Another possible variant of squamous carcinoma is the "NUT midline carcinoma" (NMC), a rare form of undifferentiated carcinoma with a clinical aggressive behavior and chromosomal rearrangements of the NUT (nuclear protein in testis) gene, at 15q14 [36,37].

\subsection{Lymphoepithelial Carcinoma}

Lymphoepithelial carcinoma is an undifferentiated carcinoma, in which the epithelial neoplastic population is accompanied by a strong lymphocyte infiltration. It is morphologically similar to the undifferentiated nasopharyngeal carcinoma; furthermore, both entities are usually positive for Epstein Barr Virus (EBV). Especially in Western countries, it is a rare histotype mainly affecting male adults. Microscopically, lymphoepithelial carcinoma is characterized by large medium-sized epithelial cells, blistering nucleus, and prominent nucleole, without evidence of keratinization. During the diagnostic phase, it is fundamental to differentiate lymphoepithelial carcinoma from multiple lymphomas and undifferentiated carcinomas through immunohistochemical analysis of cytokeratins and EBV antigens expression [38,39].

\subsection{Undifferentiated Sinonasal Carcinoma (SNUC)}

The 2005 WHO classification defined undifferentiated sinonasal carcinoma as a very aggressive, undifferentiated, and not EBV-associated carcinoma [38-40]. It is generally diagnosed at an advanced stage and shows an extensive invasion of adjacent anatomical structures. Histologically, it appears as undifferentiated medium-large cells neoplasia, arranged in nests and in a trabecular or solid pattern. It has a strong mitotic activity, frequent areas of necrosis, and invasion of lymph-vascular spaces. The immunohistochemical profile is characterized by the expression of cytokeratins 7,8 , and 19 [40-43]. SNUC must be distinguished from lymphoepithelial carcinoma and neuroblastoma of the olfactory tract, which is negative for the expression of cytokeratins.

\subsection{Sinonasal Adenocarcinomas}

Adenocarcinomas represent about $20 \%$ of the malignant neoplasms of the sinonasal tract [32] and they can arise from both the lining surface epithelium and the seromucinous glands (Figure 1A,B). WHO 2005 classification groups them into three main types, including intestinal adenocarcinoma (ITAC), non-intestinal adenocarcinomas (NO-ITAC), and salivary adenocarcinomas. Intestinal and non-intestinal types are surface-type adenocarcinomas, while salivary adenocarcinomas originate from seromucous glands of the nasal cavity and paranasal sinuses, as well as the surface epithelium. These carcinomas are similar to those originating from major and minor salivary glands [43-46].

A

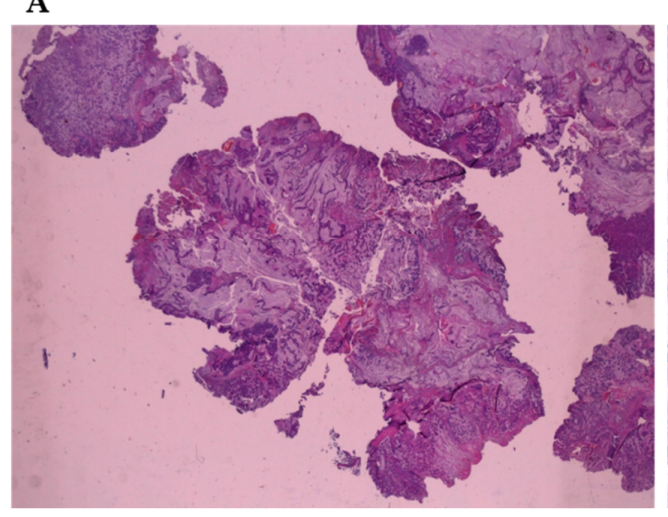

B

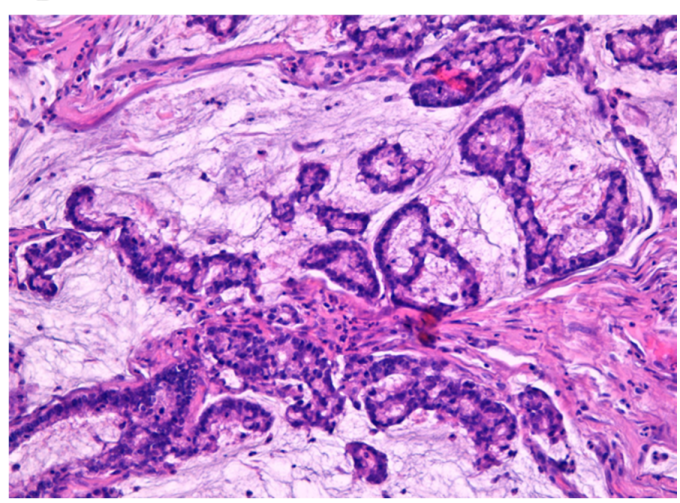

Figure 1. (A) Mucinous sinonsal adenocarcinoma $(4 \times)$ stained with hematoxylin-eosin. (B) Mucinous sinonsal adenocarcinoma $(40 \times)$ stained with hematoxylin-eosin. 


\subsection{Intestinal Adenocarcinoma}

Intestinal-type adenocarcinoma (ITAC) has histological features similar to adenoma and colorectal adenocarcinoma from which it must be differentiated (Figure 2). ITAC originates from areas of intestinal metaplasia of the Schneiderian mucosa, which covers the sinus-nasal district. It is the most frequent type of adenocarcinoma, accounting for $6 \%$ to $13 \%$ of sinonasal malignancies. It affects more frequently male subjects (male:female ratio up to $6: 1)[22,43-46]$ with a peak in the fifth and sixth decade of life. The most frequent site is the ethmoid, followed by the nasal cavities and other paranasal sinuses.

Macroscopically, it appears more often as an exophytic, polypoid, or papillary lesion, sometimes jelly-like. Microscopically, the neoplasm is constituted by cylindrical and mucussecreting cells. Neoplastic elements rarely show a "ring cell with bezel" appearance, due to the intracytoplasmic accumulation of mucins. Occasionally, elements with endocrine differentiation may be present. The architecture can be papillary, glandular, compact, mucinous, or mixed. The differentiation grade shows a correlation with the behavior of the neoplasm. For example, the mucinous and poorly differentiated forms, with a solid architecture, are significantly more aggressive than well-differentiated or moderately differentiated forms, with papillary or tubule-glandular architectural patterns [47]. They are also described in the literature as rare examples of ITAC combined with small cell neuroendocrine carcinoma [45]. The immune phenotype of the ITAC is characterized by positivity for cytokeratins 7 and 20 and for intestinal differentiation markers. In particular, cytokeratin 7 is frequently but not constantly positive, while cytokeratin 20 is positive in almost all cases, together with CDX2 [48-52]. The presence of cytological atypia, high mitotic index, and areas of necrosis are helpful in the distinction of ITAC from either benign lesions, such as mucocele, or non-intestinal type adenocarcinomas with a low grade of histological malignancy. The absence of squamous differentiation distinguishes ITAC from mucoepidermoid carcinoma and adenosquamous carcinoma [49,50,53,54]. Molecular alterations observed in ITACs are mainly mutations in the TP53 genes (60\%) [54] and overexpression of EGFR or HER2 (30\%) [55-58]. The rate of TP53 mutations in ITACs is about $60 \%$ and, interestingly, it is related to the duration, average and cumulative level of exposure to wood dust [53-55].

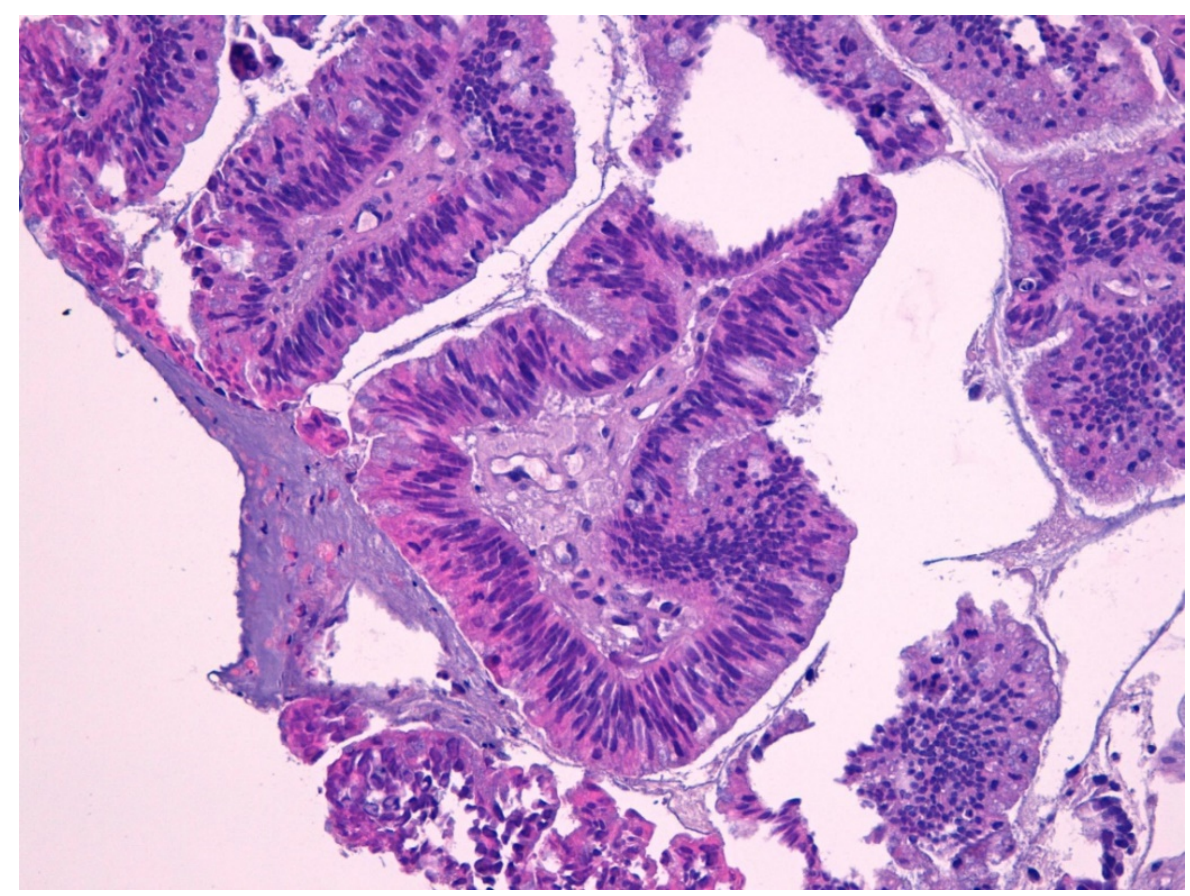

Figure 2. Intestinal type adenocarcinoma $(40 \times)$ stained with hematoxylin-eosin. 


\subsection{Non-Intestinal Adenocarcinomas}

Non-intestinal sinonasal adenocarcinomas (non-ITAC) are a rare and heterogeneous group of undifferentiated tumors, sharply different from salivary histotypes. They can be further distinguished into low- and high-grade forms. More aggressive non-intestinal adenocarcinomas mainly affect nasal cavities and maxillary sinus of male subjects. Conversely, low-grade non-intestinal adenocarcinomas are located preferentially in the nasal cavities and ethmoidal sinus of adult subjects. Histological studies show that they are positive for cytokeratin 7, but not for cytokeratin 20 and CDX2 [59-61]. Furthermore, papillary glandular, mucinous, trabecular, cribriform, clear cells (renal carcinoma type) pattern of growth can be identified [61-64]. In any case, these are well-differentiated cancers, with absent or mild atypia, and low mitotic index. In fact, they need to be distinguished from benign lesions, such as adenomatoid epithelial respiratory hamartoma and mucinous serum hamartoma.

\subsection{Salivary Adenocarcinomas}

Salivary adenocarcinomas originate from seromucous glands of the nasal cavity and paranasal sinuses, as well as from the surface epithelium. These histotypes are identical to the forms arising at the level of the minor and major salivary glands of the oral cavity. They show a cribriform architecture in about $50 \%$ of the cases, while in the remaining cases they have a solid or tubular architecture. Bone and nerve sheath invasion can be frequently observed. Sinonasal salivary-type carcinomas include different tumor types such as adenoid cystic carcinoma, mucoepidermoid carcinoma, acinic cell carcinoma (Figure 3A,B), myoepithelial carcinoma, epithelial-myoepithelial carcinoma, polymorphous low-grade adenocarcinoma, and carcinoma ex-pleomorphic adenoma $[62,65,66]$. Adenoid cystic carcinoma (Figure 4) is the most frequent histology, accounting for about $10 \%$ to $18 \%$ of TuNSs, and it is preferentially located at the level of the maxillary sinus and nasal cavities [62,65-68]. HPV infections sustained by HPV33 and HPV35 are frequently associated with its onset $[35,62,69,70]$. However, given the small number of cases studied so far, these findings need to be confirmed further. The less common form is the mucoepidermoid carcinoma, representing about $5 \%$ of sinonasal glandular tumors $[62,71]$.

A

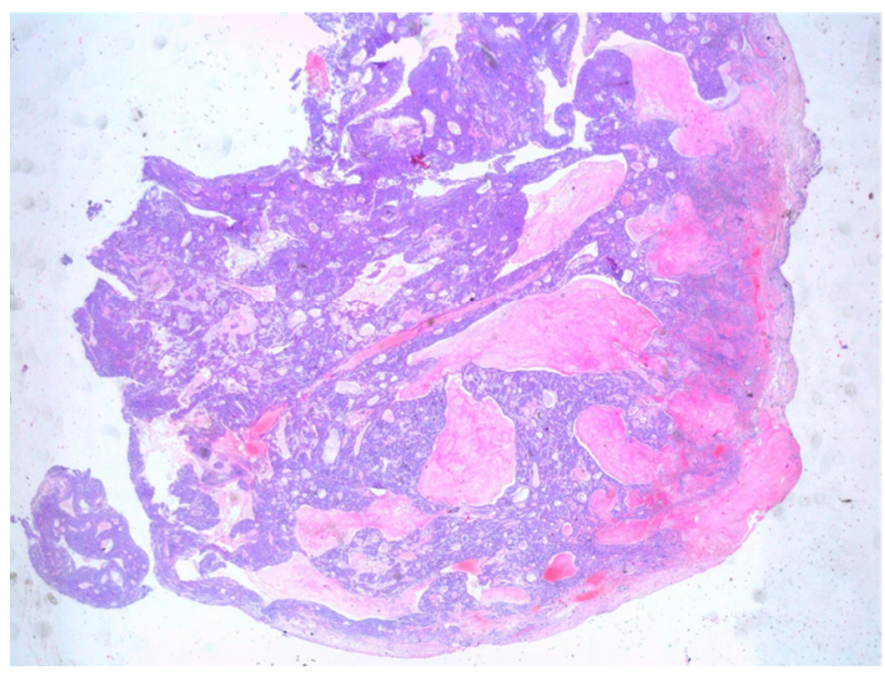

B

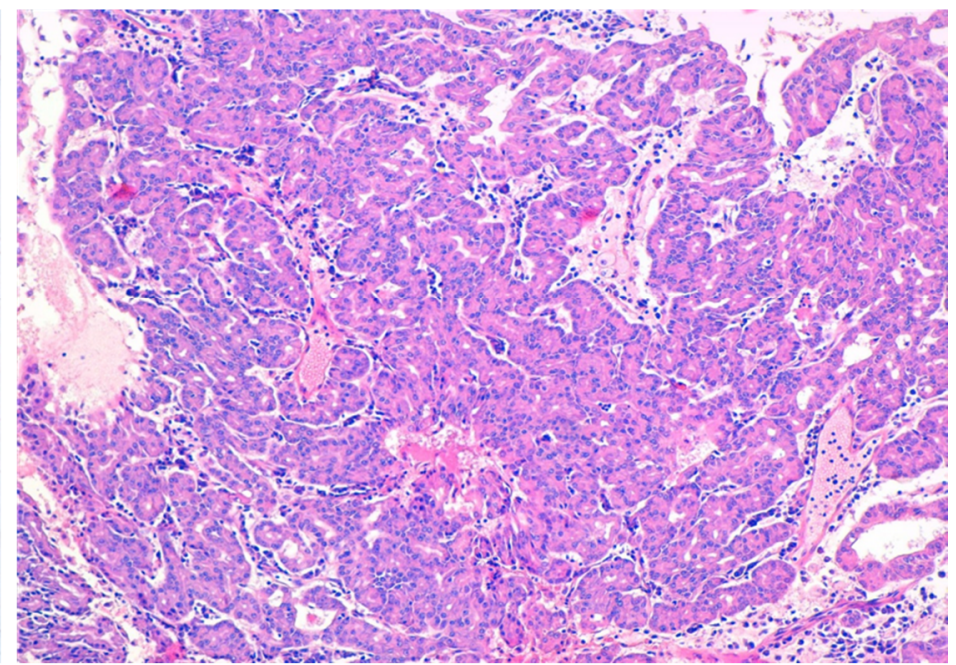

Figure 3. (A) Acinic cell carcinoma $(4 \times)$ stained with hematoxylin-eosin. (B) Acinic cell carcinoma $(40 \times)$ stained with hematoxylin-eosin. 


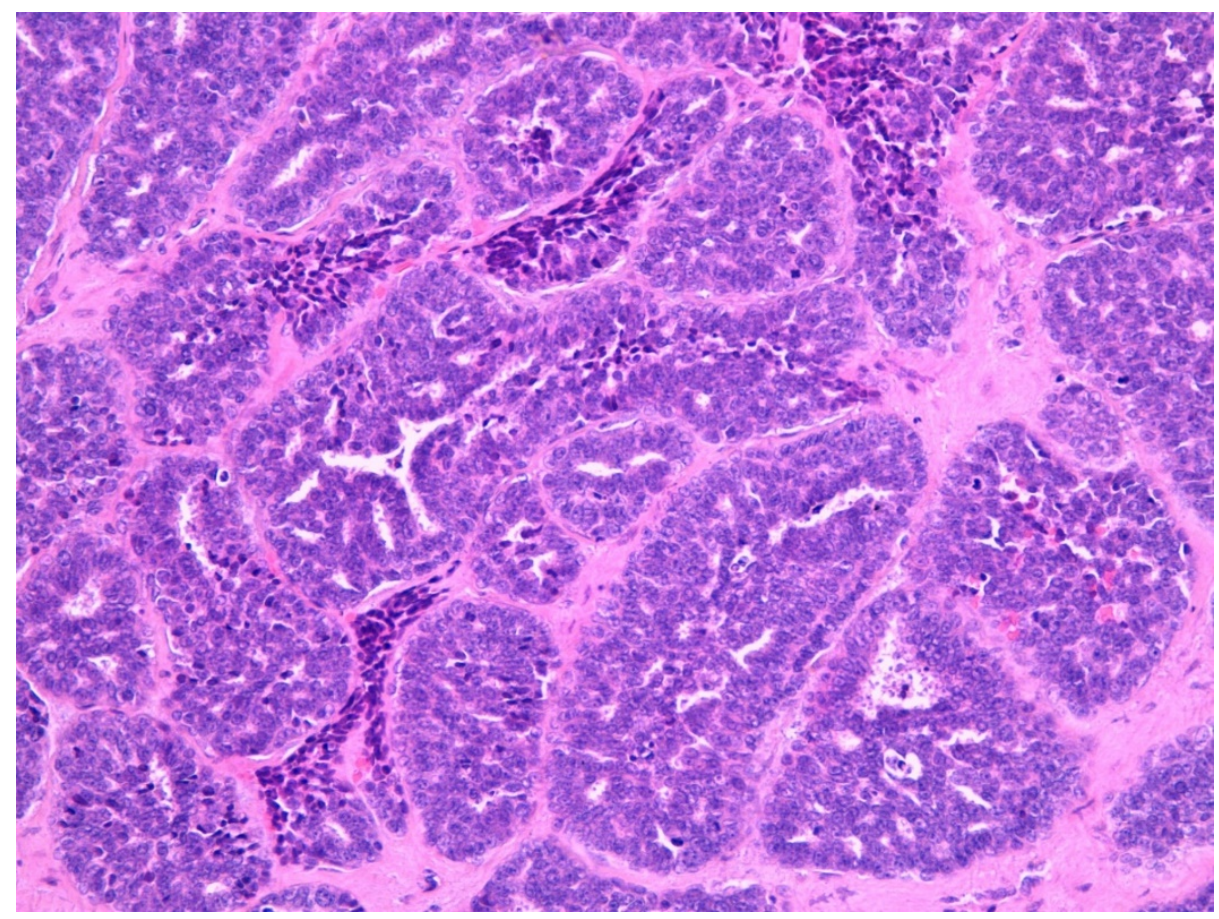

Figure 4. Adenoid cystic carcinona $(40 \times)$ stained with hematoxylin-eosin.

\subsection{Neuroendocrine Tumors (NENs)}

Primary TuNSs with neuroendocrine differentiation (SCND or Sinonasal Neuroendocrine Tumors-NENs) are infrequent tumors with histologic features similar to neuroendocrine carcinomas arising in other sites [72-74]. The classification is based on mitotic activity, necrosis, and nuclear pleomorphism. Sinonasal neuroendocrine tumors are divided into well- and moderately differentiated, (grade 1 and grade 2, SNECs) and undifferentiated (grade 3 neuroendocrine carcinoma, SNUC). Moreover, SNECs are sub-divided into small cell (SCNECs) and large cell (LCNECs) carcinomas. The use of the Ki-67 labeling index has been suggested as an additional objective criterion $[13,75,76]$. In general, conventional microscopy is not sufficient to make a definitive diagnosis, thus, immunohistochemistry studies are required. Sinonasal neuroendocrine carcinomas are usually strongly positive for synaptophysin, specific neuronal enolase (NSE), and CD56, showing a weak reaction for chromogranin and CAM5.2. The histomorphological diagnosis, along with grading and staging assessments, is crucial in predicting the prognosis of these tumors. The prognosis of sinonasal neuroendocrine carcinoma closely depends on the tumor type and grade, with high-grade carcinomas displaying the worse outcome. Sinonasal neuroendocrine carcinomas must be distinguished from olfactory neuroblastoma (ONB). The later is a neuroectodermal neoplasia presenting very similar histological features with neuroendocrine forms, especially in poorly differentiated histotypes. However, the sustentacular cells of an olfactory neuroblastoma are negative for cytokeratins (at different molecular weights) and positive for the S100 cellular protein.

\subsection{Olfactory Neuroblastoma (ONB)}

Olfactory neuroblastoma (ONB), also known as esthesioneuroblastoma, is a rare malignant tumor arising from the olfactory neuroepithelium of the superior nasal cavity. First described by Berger in 1924, it accounts for approximately 2-3\% of tumors of the nasal cavity, without any race or gender predilection. It is divided by the Hyams' histologic grading system in low-grade (Hyams I-II) and high-grade (Hyams III-IV) tumors, the first characterized by a lobular architecture with a minimal or absent mitotic activity and the presence of pseudorosettes, the second by the gradual loss of the lobular architecture, a more represented mitotic activity, and the emergence of necrosis. Molecular analysis 
shows overexpression of the Drosophila achaete-scute gene (hASH1) involved in immature olfactory neuronal development and in neuroendocrine differentiation. Prognostic factors and specific guidelines for ONB treatment are not well-defined, mainly due to the rarity of these neoplasms and the scarcity of studies with large case numbers. So far, treatment schemes include surgery, radiation therapy, and chemotherapy (as adjuvant or neoadjuvant) in various combinations [77].

\section{Genetic Background of Paranasal Sinus Carcinomas}

The carcinogenesis of TuNSs, regardless of their histology, depends on exposure to many different risk factors (see above Table 1). They do not have a direct carcinogenesis mechanism, as they are not mutagenic. The main carcinogenetic mechanism is the stimulation of a chronic and sustained inflammatory status. A complete dissertation of links between cancer and chronic inflammation is beyond the scope of this review. However, the continuous production of IFN $\alpha$ and IL-1 $\beta$ by lymphocytes and/or inflammatory infiltrate cells stimulates the transcription factor nuclear factor $\kappa B(N F \kappa B)$ pathway. The latter pathway is associated with cell proliferation and cell cycle dysregulation within epithelial cells [78]. Another mechanism is the uncontrolled production of reactive oxygen species (ROS) which are overproduced in chronic inflammation. They cause direct damage of DNA (inactivation of tumor suppressor genes and/or the activation of oncogenes), facilitates neoplastic progression [79].

TuNSs present specific genetic signatures and altered signaling pathways. The most frequent mutated gene is TP53 (60\% of TuNSs). The frequency of TP53 mutations is even more high in specific histotypes from ITACs (80\%). Most of the mutations are missense with loss or attenuation of function and overexpression at IHC of the related protein. Interestingly, chronic exposure to wood and leather dust, through sustained inflammation, causes mutations that preferentially affect TP53 [80,81]. Another change frequently found in TuNSs is related to the Wnt/ $\beta$-catenin pathway. Under normal conditions, $\beta$-catenin interacts with receptors of the APC family (adenomatous polyposis of the colon) and this interaction leads to the ubiquitination of the $\beta$-catenin. In the presence of overexpressed Wnt, $\beta$-catenin mainly interacts with it and switches on translocating into the nucleus. In nucleus, it acts as a transcription factor, activating the genes encoding for Cycline D1 and $\mathrm{C}-\mathrm{Myc}$, finally causing cell cycle dysregulation. Activating mutations of Wnt are detected in $30-50 \%$ of the paranasal sinus tumors $[82,83]$. Furthermore, about $20-30 \%$ of TuNSs are characterized by the overexpression of EGFR (epithelial growth factor receptor) at the protein level. This overexpression correlates either with amplification of the EGFR gene or with hyper-activating point mutations [84]. Often EGFR overexpression is mutually exclusive with overexpression of the p16 protein, which in turn correlates with HPV infection. Two prognostic groups can be identified: p16-positive/EGFR-negative TuNSs associated with better prognosis and p16-negative/EGFR-positive TuNSs associated with worse prognosis. These molecular features are also common for several tumors of the head and neck area [85]. Finally, on a genetic basis, SNUCs can be divided into: NUT (midline) carcinoma, SMARB1-deficient carcinoma, SMARCA4-deficient carcinoma and IDH-mutant carcinoma. The NUT carcinoma is characterized by the NUT-BRD4 gene fusion, with the generation of a chimeric protein able to dysregulate the cell cycle. SMARB1 is a tumor suppressor gene which once mutated is inactivated with consequent loss of function leading to a cell cycle dysregulation. SMARCA4 is another tumor suppressor gene whose function is very similar to that of SMARB1, namely, it is involved in the chromatin assembly. Loss of function of SMARCA4 characterizes the SMARCA4-carcinomas. IDH (isocitrate dehydrogenase) is an enzyme involved in metabolism. In normal conditions, this enzyme degrades isocitrate into hydroxyglutarate, a nutrient used to generate energy for the cell. When mutated, the aberrant enzymatic function of isocitrate dehydrogenase leads to an overproduction of hydroxyglutarate, a potent oncometabolite. This oncometabolite is translocated to the nucleus, where it causes widespread hypermethylation in gene 
promoter regions, thus silencing genes involved in cell differentiation and regulation of proliferation $[86,87]$.

\section{Clinical Aspects and Prognosis}

TuNSs generally do not show specific symptoms to allow for an early diagnosis. In fact, they are often discovered during medical examinations carried out for other reasons. These tumors usually grow locally, extending to nearby structures (e.g., orbit, oral cavity, nasopharynx, and cranial base) and rarely to neck lymph nodes (especially submandibular, latero-cervical lymph nodes). They have scarce ability to spread at distant organs, however, less differentiated types (such as poorly differentiated and undifferentiated carcinoma) are more prone to metastasis. Sometimes, they become symptomatic when they extend to surrounding tissues with worsening abnormal nasal congestion, obstruction of a nostril, persistent epistaxis, nasal muchorrea, anosmia, abnormal protrusion of the eyeball, diplopia or loss of vision, ear pain or compression feeling, continuous tearing, headache, masses into nose and/or palate, neck lymph node enlargement, unexplained face distortions, etc. (Table 3). Prognostic factors include age, performance status, tumor location and local extension, histotype, presence or lack of perineural invasion. For example, about the precise site of origin, carcinomas arising from the nasal cavity show a better prognosis than those from the paranasal sinuses, likely because nasal carcinomas give rise to symptoms (e.g., nasal obstruction or epistaxis) coming earlier to clinical attention [1-5,10,14,16,17]. In addition, among maxillary sinus carcinomas, those arising from the anterior-inferior portion have a better prognosis than those arising from the superior-posterior portion, likely because the latter group has easier access to structures such as the orbit or skull base. Regarding staging, in patients with T1 disease, the 5-year survival rate is $80 \%$, while in patients with T4 tumors, survival decreases to $30 \%$. Extensive local disease involving nasopharynx, skull base, or cavernous sinuses markedly increases both surgical morbidity and local recurrence within 2 years [78-81]. In particular, maxillary sinus tumors are associated with $30-70 \%$ survival rate at 5 years after appropriate surgical excision; however, this value quickly drops to $10-20 \%$ in the case of unresectable disease [55,88-91]. For ITAC, the probability to be alive at 5 years is about $50 \%$ after surgery and postoperative chemo-radiotherapy. These tumors usually grow locally, destroying nearby structures. They rarely involve locoregional lymph nodes (such as submandibular and laterocervical nodes) and even less frequently give distant metastases which are more typical of the undifferentiated tumor.

Table 3. Sinonasal neuroendocrine tumors: common symptoms.

\begin{tabular}{l}
\hline Nasal congestion that does not improve; \\
- $\quad$ Obstruction of a nostril; \\
- $\quad$ Persistent loss of blood, mucus, or pus from the nose; \\
- $\quad$ Pain in the region around the eye; \\
- $\quad$ Anomalous protrusion of an eyeball; \\
- $\quad$ Diminished sense of smell; \\
- Change in vision, a headache never experienced before, mass formation in the nose/palate.
\end{tabular}




\section{Treatment Option Overview}

Surgery represents the mainstay of the treatment. However, the diagnosis is generally made in late phases when the tumor has infiltrated local structures and surgical removal is challenging. Treatment should be individualized based on location and extent of disease, patient performance status, histopathologic subtype, and availability of local expertise. Due to the rarity of these tumors, patients should be referred to centers with high expertise in their management. Studies have shown that surgery gives fairly good results. Surgery produces excellent control rates for T1 and T2 tumors (Figure 5A-D and Figure 6A-D). In this context, every lesion should be evaluated by the surgeon. In fact, for small and localized tumors, surgery can achieve R0 margins allowing the entire tumor's removal, even by less invasive methods (for example, by endoscopic access). However, in most cases (including T2 tumors or adenoid cystic carcinoma), $\mathrm{RT}$ is given postoperatively (Figures 7 and $8 \mathrm{~A}-\mathrm{D}$ ) even if the resection margins are negative (R0). The volume to be irradiated should include the "tumor bed", but also the neighboring lymph node levels. In fact, in some situations, such as infiltration of the pre-vertebral fascia, infiltration of the parotid and poorly differentiated tumors, prophylactic irradiation of the lymph nodes, even if clinically negative, should be considered. Adjuvant chemo-radiotherapy should be considered in presence of an involved or inadequate resection margin (R1). Notably, radical surgery, particularly in bulky tumors, should be always followed by reconstruction techniques. Radical neck dissection (levels I-V according to Robbins classification) or elective radiation therapy of the whole neck is prescribed only for patients presenting with positive neck nodes $(\mathrm{N}+)$. The incidence of lymph node metastases is generally low (approximately $20 \%$ of all cases). Maxillary sinus and ethmoid sinus tumors in most cases present as locally advanced disease (large T3 or T4) and they are commonly managed with surgery and postoperative chemo-radiation therapy. Cancers of the skull base, nasopharynx, or sphenoid sinus very often cannot be surgically removed. Concurrent chemo-radiation therapy may also be used for patients with comorbidities contraindicating surgery. Cisplatin or carboplatin single-agent with external beam radiation can be used in locally advanced and unresectable squamous cell carcinomas. In this case, last-generation radiotherapy techniques may be applied, such as Intensity Modulated Radiation Therapy (IMRT) and hadrontherapy [90-96]. Some histologies, such as ITAC and adenoid-cystic, are scarcely responsive to chemotherapy; in these cases, the use of radiotherapy should be considered. At this regard, data concerning the use of proton therapy in TuNSs (from one-institutional retrospective studies and systematic reviews) indicate both a better efficacy and activity of this therapy, compared to photon radiotherapy [97,98]. In summary, radio- and chemotherapy should be taken into account postoperatively as adjuvant treatments based on clinical and pathological risk factors. By contrast, locally advanced lesions often require more demolitive surgery and the radical resection should be always followed by adjuvant radio- or chemo-radiotherapy. If surgery is not feasible due to the extent of the disease, or to the presence of severe comorbidities, radiotherapy remains a curative treatment option, and whenever possible, it should be accompanied with chemotherapy. Notably, data from the literature show significant improvement of survival in patients treated with the combination of two or more multidisciplinary approaches (surgery, chemotherapy, and radiotherapy). Locally advanced/unresectable disease can still be approached with a curative intent attitude. In fact, even if not the best choice, sequential chemo-radiotherapy treatment, or alternatively, induction chemotherapy followed by surgery, should be evaluated. The chemotherapy regimens used in clinical practice are the same as those used for squamous neoplasms of the head and neck area and include combinations of platinum, fluoropyrimidines, and taxanes [99,100]. For recurrent/metastatic disease, the objective is to obtain disease long-term control throughout palliative chemo- and/or radiotherapy. The latter should be used for treating symptomatic sites or those at risk of bleeding or fracture. 


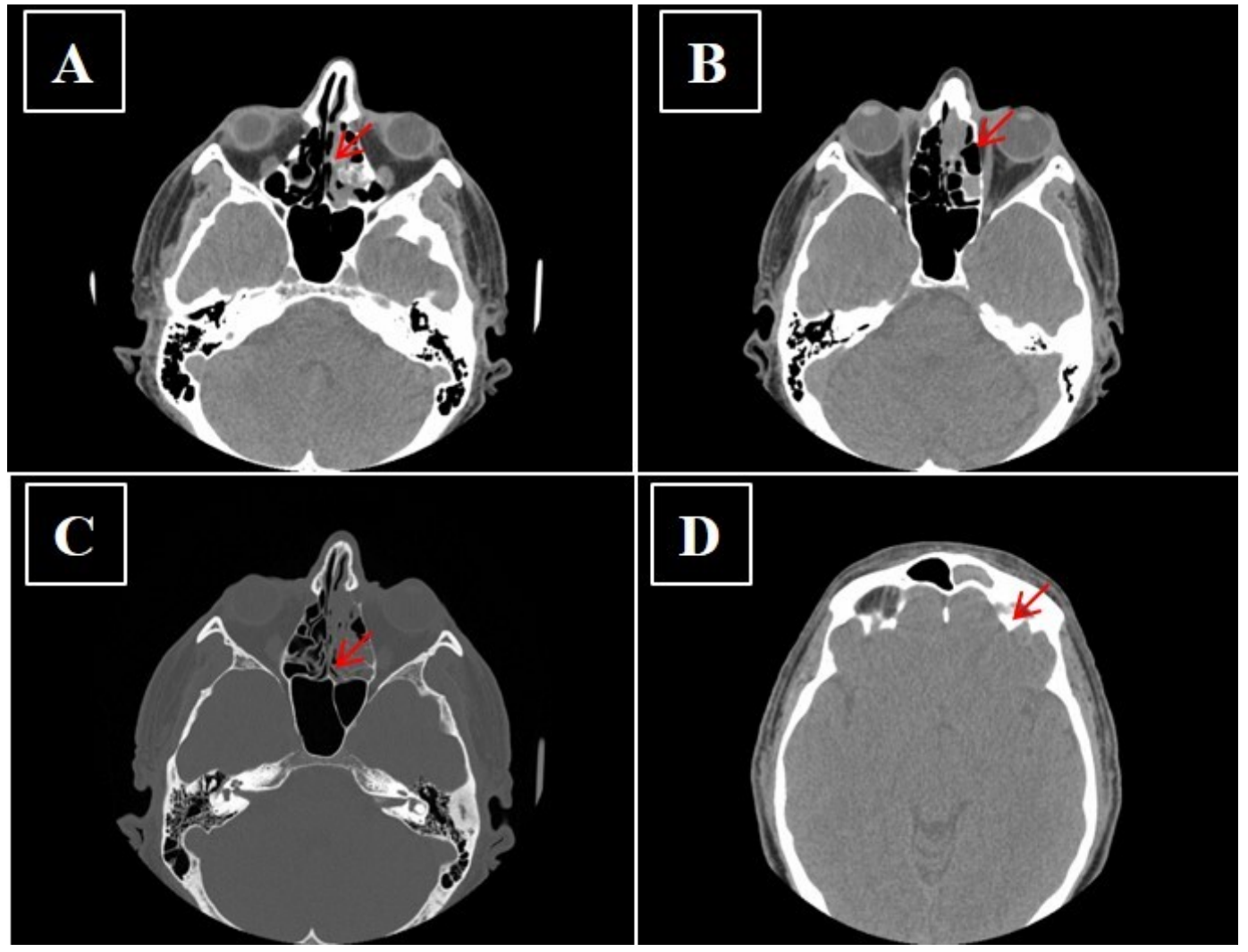

Figure 5. (A-D) No-contrast media CT showing sinonasal neuroendocrine tumors-MENs of ethmoidal cells and to left frontal sinus before surgery (arrow).

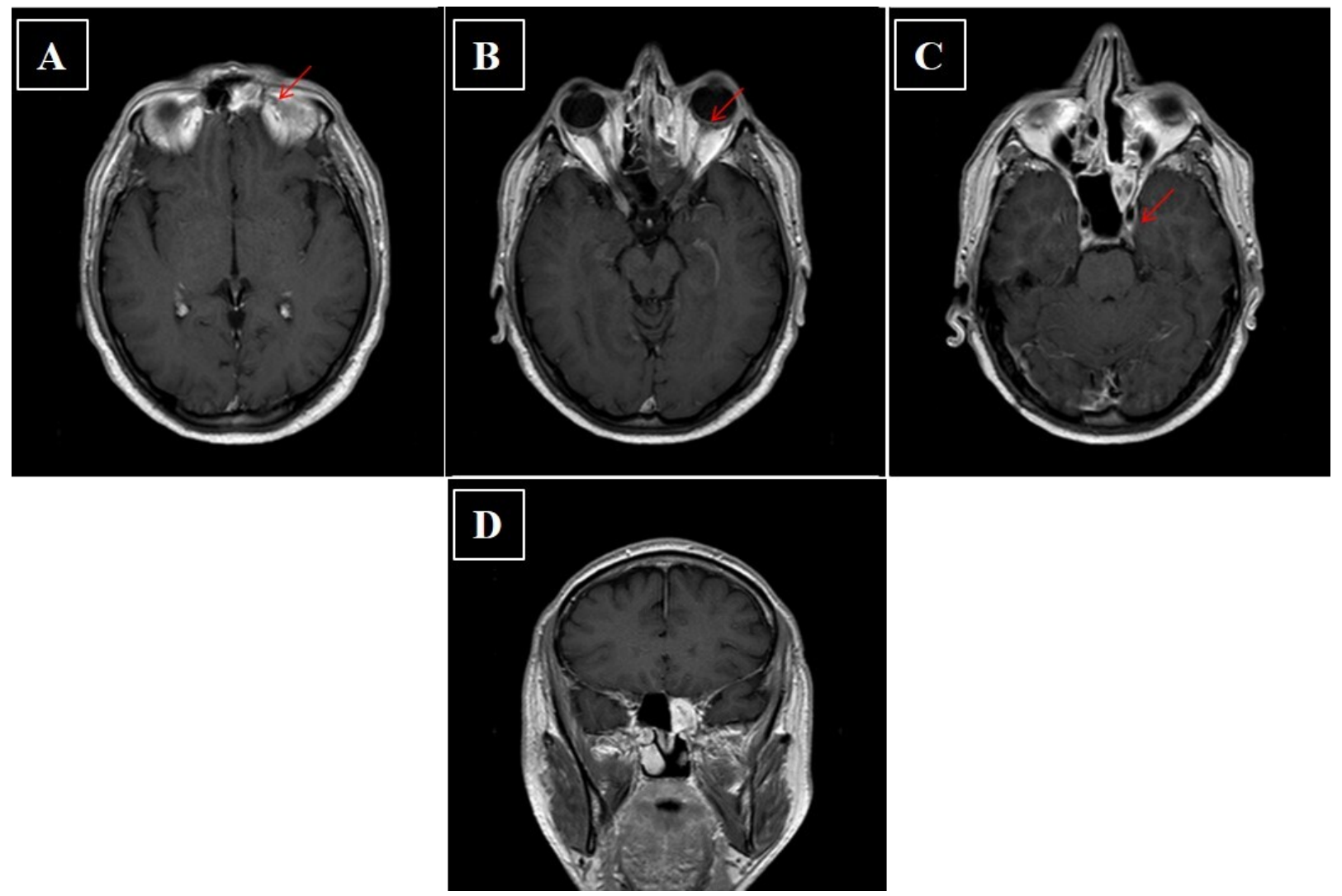

Figure 6. (A-D) Axial and coronal contrast enhanced fat-suppressed T1-weighted image CT scan of head performed after surgery. The arrow indicates persistence of inflammatory tissue. 


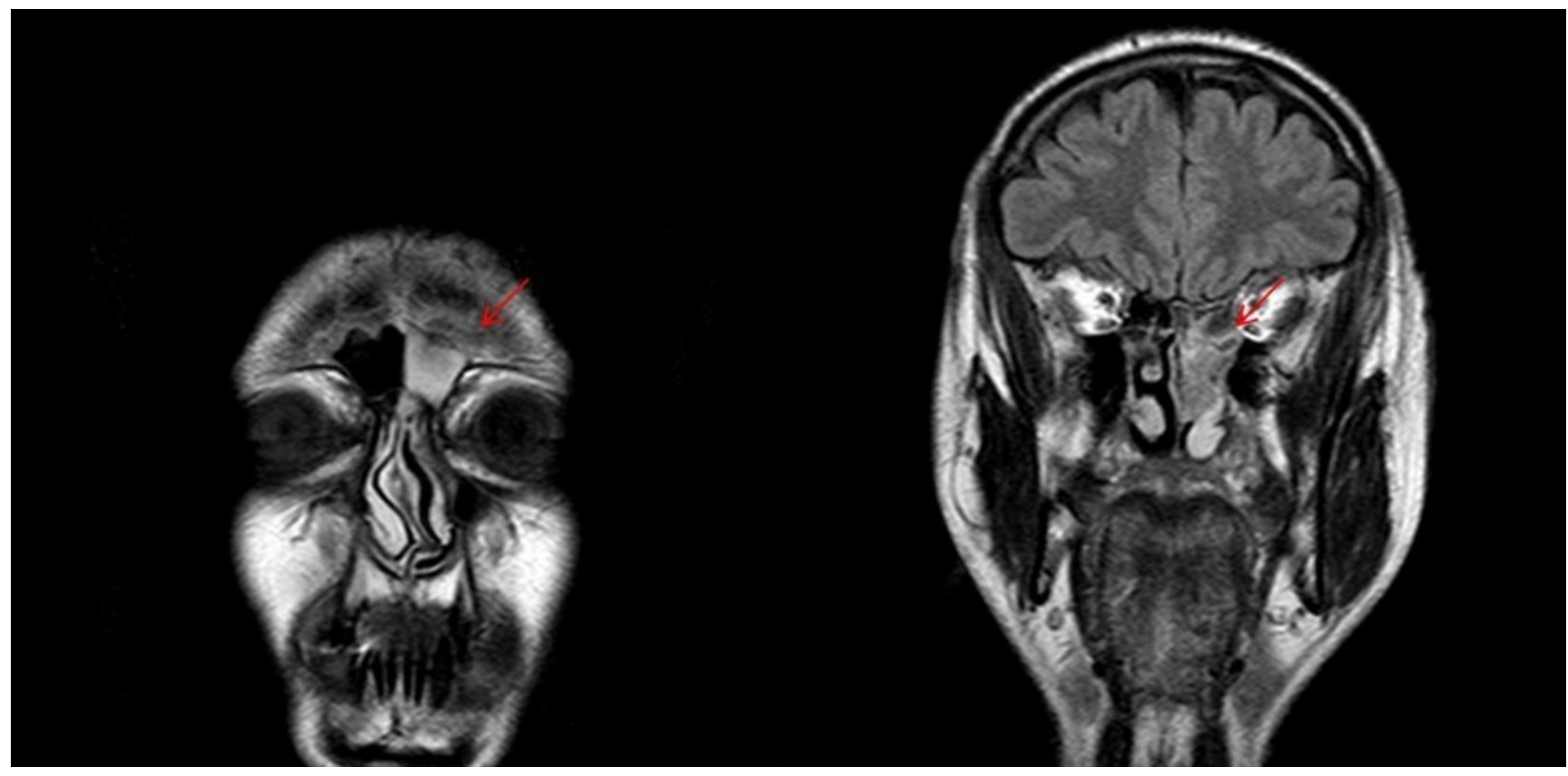

Figure 7. T2-weighted MRI image showing sinonasal neuroendocrine tumors-MENs of ethmoidal cells and to left frontal sinus before radiotherapy.

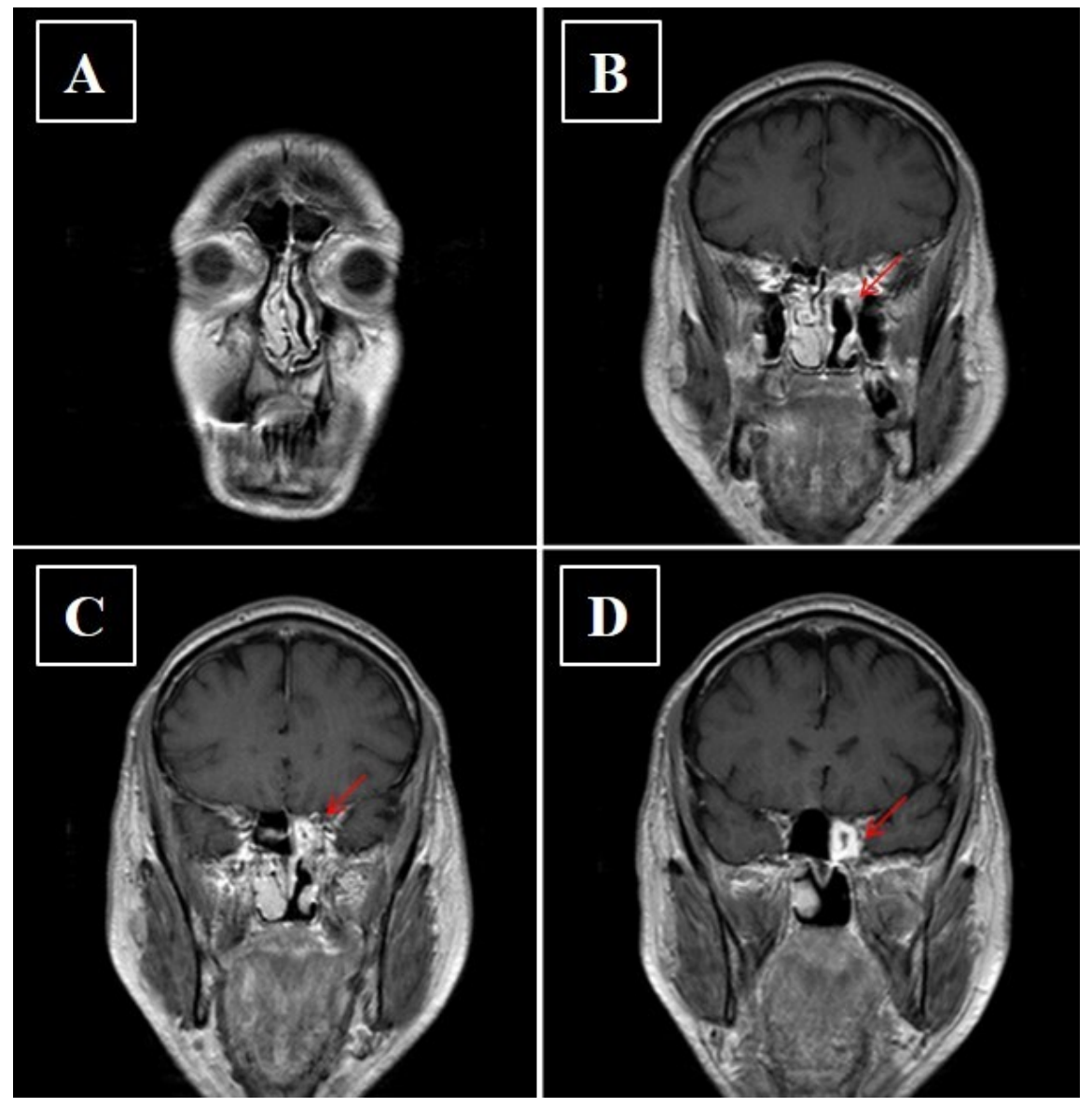

Figure 8. (A-D) Axial contrast enhanced fat-suppressed T1-weighted image showing reduction of the pathological tissue component in the upper offshoot of the ethmoid after adjuvant radiotherapy. 


\section{Conclusions}

TuNSs are rare cancers, with a prevalence of much less than $1 \%$ in the general population. Well-validated therapeutic strategies are lacking as it is difficult to carry out randomized clinical trials. In general, a multimodal and multidisciplinary approach should always be pursued to overcome this gap. In the near future, both diagnosis and treatment of TuNSs will be improved through an increasing amelioration of their genetic assessment. In particular, the identification of druggable "key driver" mutations will revolutionize the treatment and change the natural history of the disease.

Author Contributions: Conceptualization, A.B. and S.T.; methodology, A.O.; software, G.D.L.; validation, F.P., and G.D.L.; writing—original draft preparation A.B., A.O. and O.C.; writing-review and editing A.B., G.D.L.; data curation, R.T., M.S.; resources F.T., M.L.B. and N.S.L.; supervision, S.T. All authors have read and agreed to the published version of the manuscript.

Funding: This research received no external funding.

Acknowledgments: We thank the non-profit organization Lega Italiana Per La Lotta Contro i Tumori (LILT) of Na-ples and Alessandra Trocino, Librarian at the Library of Istituto Nazionale Tumori Fonda-zione 'G Pascale', Naples, Italy, for her excellent bibliographic service and assistance.

Conflicts of Interest: The authors declare no conflict of interest.

\section{References}

1. Dutta, R.; Ba, P.M.D.; Svider, P.F.; Liu, J.K.; Baredes, S.; Eloy, J.A. Sinonasal malignancies: A population-based analysis of site-specific incidence and survival. Laryngoscope 2015, 125, 2491-2497. [CrossRef]

2. Patel, T.D.; Vazquez, A.; Dubal, P.M.; Baredes, S.; Liu, J.K.; Eloy, J.A. Sinonasal neuroendocrine carcinoma: A population-based analysis of incidence and survival. Int. Forum Allergy Rhinol. 2015, 5, 448-453. [CrossRef]

3. Thariat, J.; Plana, A.M.; Vérillaud, B.; Vergez, S.; Régis-Ferrand, F.; Digue, L.; Even, C.; Costes, V.; Baujat, B.; De Gabory, L.; et al. Diagnostic, pronostic et traitement des carcinomes nasosinusiens (hors mélanomes, sarcomes et lymphomes). Bull Cancer 2020, 107, 601-611. [CrossRef]

4. Abdelmeguid, A.S.; Bell, D.; Hanna, E.Y. Sinonasal Undifferentiated Carcinoma. Curr. Oncol. Rep. 2019, 21, 26. [CrossRef]

5. Agaimy, A.; Weichert, W. Grading von Tumoren der Kopf-Hals-Region. Der Pathol. 2016, 37, 285-292. [CrossRef] [PubMed]

6. El Ayoubi, A.; Poizat, F.; Garrel, R.; Costes, V.; Guerrier, B.; Essakalli, L.; Kzadri, M.; Crampette, L. Les adénocarcinomes nasosinusiens revisités. Intérêt pronostique de la classification histologique OMS 2005. Ann. d'Otolaryngologie et de Chir. Cervico-faciale 2009, 126, 175-181. [CrossRef]

7. Rosenthal, D.I.; Barker, J.L., Jr.; El-Naggar, A.K.; Glisson, B.S.; Kies, M.S.; Diaz, E.M.; Clayman, G.L.; Demonte, F.; Selek, U.; Morrison, W.H.; et al. Sinonasal malignancies with neuroendocrine differentiation: Patterns of fail-ure according to histologic phenotype. Cancer 2004, 101, 2567-2573. [CrossRef] [PubMed]

8. Lombardo, N.; Della Corte, M.; Pelaia, C.; Piazzetta, G.; Lobello, N.; Del Duca, E.; Bennardo, L.; Nisticò, S. Primary Mucosal Melanoma Presenting with a Unilateral Nasal Obstruction of the Left Inferior Turbinate. Medicina 2021, 57, 359. [CrossRef]

9. Bishop, J.A. Recently described neoplasms of the sinonasal tract. Semin. Diagn. Pathol. 2016, 33, 62-70. [CrossRef] [PubMed]

10. Quan, H.; Yan, L.; Zhang, H.; Zou, L.; Yuan, W.; Wang, S. Development and validation of a nomogram for prognosis of sinonasal squamous cell carcinoma. Int. Forum Allergy Rhinol. 2019, 9, 1030-1040. [CrossRef] [PubMed]

11. Mensi, C.; Consonni, D.; Sieno, C.; De Matteis, S.; Riboldi, L.; Bertazzi, P.A. Sinonasal Cancer and Occupational Exposure in a Population-Based Registry. Int. J. Otolaryngol. 2013, 2013, 1-7. [CrossRef] [PubMed]

12. Bossi, P.; Farina, D.; Gatta, G.; Lombardi, D.; Nicolai, P.; Orlandi, E. Paranasal sinus cancer. Crit. Rev. Oncol. 2016, 98, 45-61. [CrossRef] [PubMed]

13. Sirsath, N.T.; Babu, K.G.; Das, U.; Premlatha, C.S. Paranasal Sinus Neuroendocrine Carcinoma: A Case Report and Review of the Literature. Case Rep. Oncol. Med. 2013, 2013, 728479. [CrossRef] [PubMed]

14. Jayme, E.M.; Morimoto, T.P.; Lozano, T.M.; Campos, Z.M.D.S.; De Castro, C.C. Sphenoid sinus neuroendocrine carcinoma. BJR Case Rep. 2017, 3, 20150334. [CrossRef] [PubMed]

15. D’Errico, A.; Pasian, S.; Baratti, A.; Zanelli, R.; Alfonzo, S.; Gilardi, L.; Beatrice, F.; Bena, A.; Costa, G. A case-control study on occupational risk factors for sino-nasal cancer. Occup. Environ. Med. 2009, 66, 448-455. [CrossRef] [PubMed]

16. Van den Oever, R. Occupational exposure to dust and sinonasal cancer. An analysis of 386 cases reported to the N.C.C.S.F. Cancer Registry. Acta Otorhinolaryngol. Belg. 1996, 50, 19-24. [PubMed]

17. Radoï, L.; Sylla, F.; Matrat, M.; Barul, C.; Menvielle, G.; Delafosse, P.; Stücker, I.; Luce, D.; ICARE Study Group. Head and neck cancer and occupational exposure to leather dust: Results from the ICARE study, a French case-control study. Environ. Heal. 2019, 18, 27. [CrossRef] 
18. Bimbi, G.; Saraceno, M.S.; Riccio, S.; Gatta, G.; Licitra, L.; Cantù, G. Adenocarcinoma of ethmoid sinus: An occupational disease. Acta Otorhinolaryngol. Ital. 2004, 24, 199-203.

19. Nakamura, Y.; Suzuki, M.; Ozaki, S.; Yokota, M.; Nakayama, M.; Hattori, H.; Inagaki, H.; Murakami, S. Sinonasal inverted papilloma associated with small cell neuroendocrine carcinoma: A case report and literature review of rare malignancies associated with inverted papilloma. Auris Nasus Larynx 2019, 46, 641-650. [CrossRef] [PubMed]

20. Gupta, R.; Rady, P.L.; Sikora, A.G.; Tyring, S.K. The role of human papillomavirus in the pathogenesis of sinonasal inverted papilloma: A narrative review. Rev. Med Virol. 2021, 31, e2178. [CrossRef] [PubMed]

21. Carton, M.; Goldberg, M.; Luce, D. Occupational exposure to wood dust. Health effects and exposure limit values. Revue d'Épidémiologie et de Santé Publique 2002, 50, 159-178. [PubMed]

22. Jayaprakash, V.; Natarajan, K.K.; Moysich, K.B.; Rigual, N.R.; Ramnath, N.; Natarajan, N.; Reid, M.E. Wood dust exposure and the risk of upper aero-digestive and respiratory cancers in males. Occup. Environ. Med. 2008, 65, 647-654. [CrossRef] [PubMed]

23. IARC Working Group on the Evaluation of Carcinogenic Risks to Humans. Tobacco smoke and involuntary smoking. IARC Monogr. Eval. Carcinog. Risks Hum. 2004, 83, 1-1438.

24. Larque, A.B.; Hakim, S.; Ordi, J.; Nadal, A.; Diaz, A.; Del Pino, M.; Marimon, L.; Alobid, I.; Cardesa, A.; Alos, L. High-risk human papillomavirus is transcriptionally active in a subset of sinonasal squamous cell carcinomas. Mod. Pathol. 2013, 27, 343-351. [CrossRef] [PubMed]

25. Thavaraj, S.; Information, P.E.K.F.C. Human papillomavirus-associated neoplasms of the sinonasal tract and nasopharynx. Semin. Diagn. Pathol. 2016, 33, 104-111. [CrossRef] [PubMed]

26. Kashima, H.K.; Kessis, T.; Hruban, R.H.; Wu, T.C.; Zinreich, S.J.; Shah, K.V. Human Papillomavirus in Sinonasal Papillomas and Squamous Cell Carcinoma. Laryngoscope 1992, 102, 973-976. [CrossRef] [PubMed]

27. Chowdhury, N.; Alvi, S.; Kimura, K.; Tawfik, O.; Manna, P.; Beahm, D.; Robinson, A.; Kerley, S.; Hoover, L. Outcomes of HPV-related nasal squamous cell carcinoma. Laryngoscope 2017, 127, 1600-1603. [CrossRef]

28. Kılıç, S.S.; Ma, S.S.K.; Kim, E.S.; Baredes, S.; Mahmoud, O.; Gray, S.T.; Eloy, J.A. Significance of human papillomavirus positivity in sinonasal squamous cell carcinoma. Int. Forum Allergy Rhinol. 2017, 7, 980-989. [CrossRef]

29. Tsou, Y.-A.; Lin, C.-C.; Tai, C.-J.; Tsai, M.-H.; Tsai, T.-C.; Chen, C.-M. Chronic Rhinosinusitis and the Risk of Nasopharyngeal Cancer in a Taiwanese Health Study. Am. J. Rhinol. Allergy 2014, 28, e168-e172. [CrossRef] [PubMed]

30. Beachler, D.C.; Engels, E.A. Chronic Sinusitis and Risk of Head and Neck Cancer in the US Elderly Population. JAMA Otolaryngol. Neck Surg. 2017, 143, 25-31. [CrossRef] [PubMed]

31. Kawaguchi, M.; Kato, H.; Tomita, H.; Mizuta, K.; Aoki, M.; Hara, A.; Matsuo, M. Imaging Characteristics of Malignant Sinonasal Tumors. J. Clin. Med. 2017, 6, 116. [CrossRef]

32. Turner, J.H.; Reh, D.D. Incidence and survival in patients with sinonasal cancer: A historical analysis of population-based data. Head Neck 2012, 34, 877-885. [CrossRef] [PubMed]

33. Haerle, S.K.; Gullane, P.J.; Witterick, I.J.; Zweifel, C.; Gentili, F. Sinonasal Carcinomas. Neurosurg. Clin. North Am. 2013, 24, 39-49. [CrossRef] [PubMed]

34. Lewis, J.S., Jr.; Khan, R.A.; Masand, R.P.; Chernock, R.; Zhang, Q.; Al-Naief, N.S.; Muller, S.; McHugh, J.B.; Prasad, M.L.; Brandwein-Gensler, M.; et al. Recognition of nonkeratinizing morphology in oropharyngeal squamous cell carcinoma - a prospective cohort and interobserver variability study. Histopathology 2012, 60, 427-436. [CrossRef] [PubMed]

35. Bishop, J.A.; Guo, T.W.; Smith, D.F.; Wang, H.; Ogawa, T.; Pai, S.I.; Westra, W.H. Human Papillomavirus-related Carcinomas of the Sinonasal Tract. Am. J. Surg. Pathol. 2013, 37, 185-192. [CrossRef] [PubMed]

36. Hellquist, H.; French, C.A.; Bishop, J.A.; Coca-Pelaz, A.; Propst, E.J.; Correia, A.P.; Ngan, B.; Grant, R.; Cipriani, N.A.; Vokes, D.; et al. NUT midline carcinoma of the larynx: An international series and review of the literature. Histopathology 2016, 70, 861-868. [CrossRef] [PubMed]

37. Stelow, E.B.; Bellizzi, A.; Taneja, K.; Mills, S.E.; Legallo, R.D.; Kutok, J.L.; Aster, J.C.; French, C.A. NUT Rearrangement in Undifferentiated Carcinomas of the Upper Aerodigestive Tract. Am. J. Surg. Pathol. 2008, 32, 828-834. [CrossRef]

38. Kutok, J.; Wang, F. Spectrum of Epstein-Barr Virus-Associated Diseases. Annu. Rev. Pathol. Mech. Dis. 2006, 1, 375-404. [CrossRef]

39. Petersson, F. Nasopharyngeal carcinoma: A review. Semin. Diagn. Pathol. 2015, 32, 54-73. [CrossRef] [PubMed]

40. Agaimy, A.; Franchi, A.; Lund, V.J.; Skálová, A.; Bishop, J.A.; Triantafyllou, A.; Andreasen, S.; Gnepp, D.R.; Hellquist, H.; Thompson, L.D.; et al. Sinonasal Undifferentiated Carcinoma (SNUC): From an Entity to Morphologic Pattern and Back Again-A Historical Perspective. Adv. Anat. Pathol. 2020, 27, 51-60. [CrossRef] [PubMed]

41. Ejaz, A.; Wenig, B.M. Sinonasal Undifferentiated Carcinoma: Clinical and Pathologic Features and a Discussion on Classification, Cellular Differentiation, and Differential Diagnosis. Adv. Anat. Pathol. 2005, 12, 134-143. [CrossRef] [PubMed]

42. Jones, A.V.; Robinson, I.; Speight, P.M. Sinonasal undifferentiated carcinoma: Report of a case and review of literature. Oral Oncol. Extra 2005, 41, 299-302. [CrossRef]

43. Barnes, L. Intestinal-Type Adenocarcinoma of the Nasal Cavity and Paranasal Sinuses. Am. J. Surg. Pathol. 1986, 10, 192-202. [CrossRef]

44. Luce, D.; Gérin, M.; Leclerc, A.; Morcet, J.-F.; Brugère, J.; Goldberg, M. Sinonasal cancer and occupational exposure to formaldehyde and other substances. Int. J. Cancer 1993, 53, 224-231. [CrossRef] [PubMed] 
45. Tripodi, D.; Ferron, C.; Malard, O.; De Montreuil, C.B.; Planche, L.; Sebille-Rivain, V.; Roedlich, C.; Quéméner, S.; Renaudin, K.; Longuenesse, C.; et al. Relevance of both individual risk factors and occupational exposure in cancer survival studies: The example of intestinal type sinonasal adenocarcinoma. Laryngoscope 2011, 121, 2011-2018. [CrossRef] [PubMed]

46. Llorente, J.L.; Pérez-Escuredo, J.; Marcos, C.A.; Suárez, C.; Hermsen, M. Genetic and clinical aspects of wood dust related intestinal-type sinonasal adenocarcinoma: A review. Eur. Arch. Oto-Rhino-Laryngol. 2009, 266, 1-7. [CrossRef] [PubMed]

47. Franchi, A.; Gallo, O.; Santucci, M. Clinical relevance of the histological classification of sinonasal intestinal-type adenocarcinomas. Hum. Pathol. 1999, 30, 1140-1145. [CrossRef]

48. Jain, R.; Gramigna, V.; Sanchez-Marull, R.; Perez-Ordoñez, B. Composite intestinal-type adenocarcinoma and small cell carcinoma of sinonasal tract. J. Clin. Pathol. 2009, 62, 634-637. [CrossRef]

49. Klein, P.J.; Adams, W.D. Comprehensive therapeutic benefits of Taiji: A critical review. Am. J. Phys. Med. Rehabil. 2004, 83, 735-745. [CrossRef] [PubMed]

50. Saad, R.S. CDX2 as a marker for intestinal differentiation: Its utility and limitations. World J. Gastrointest. Surg. 2011, 3, 159-166. [CrossRef]

51. Projetti, F.; Serrano, É.; Vergez, S.; Bissainthe, A.-C.; Delisle, M.-B.; Uro-Coste, E. Is neuroendocrine differentiation useful to discriminate primary sinonasal intestinal-type adenocarcinomas from metastatic colorectal adenocarcinomas? J. Clin. Pathol. 2014, 68, 79-82. [CrossRef]

52. Washington, M.K.; Goldberg, R.M.; Chang, G.J.; Limburg, P.; Lam, A.K.; Salto-Tellez, M.; Arends, M.J.; Nagtegaal, I.; Klimstra, D.S.; Rugge, M.; et al. Diagnosis of digestive system tumours. Int. J. Cancer 2021, 148, 1040-1050. [CrossRef] [PubMed]

53. McKinney, C.D.; Mills, S.E.; Franquemont, D.W. Sinonasal intestinal-type adenocarcinoma: Immunohistochemical profile and comparison with colonic adenocarcinoma. Mod. Pathol. 1995, 8, 421-426. [PubMed]

54. Abecasis, J.; Viana, G.; Pissarra, C.; Pereira, T.; Fonseca, I.; Soares, J. Adenocarcinomas of the nasal cavity and paranasal sinuses: A clinicopathological and immunohistochemical study of 14 cases. Histopathology 2004, 45, 254-259. [CrossRef] [PubMed]

55. Holmila, R.; Bornholdt, J.; Heikkilä, P.; Suitiala, T.; Févotte, J.; Cyr, D.; Hansen, J.; Snellman, S.-M.; Dictor, M.; Steiniche, T.; et al. Mutations in TP53 tumor suppressor gene in wood dust-related sinonasal cancer. Int. J. Cancer 2010, 127, 578-588. [CrossRef]

56. García-Inclán, C.; López, F.; Perez-Escuredo, J.; Cuesta-Albalad, M.P.; Vivanco, B.; Centeno, I.; Balbin, M.; Suárez, C.; Llorente, J.L.; Hermsen, M.A. EGFR status and KRAS/BRAF mutations in intestinal-type sinonasal adenocarcinomas. Cell. Oncol. 2012, 35, 443-450. [CrossRef]

57. Allende, B.V.; Perez-Escuredo, J.; Martínez, N.F.; Forcelledo, M.F.F.; Pendás, J.L.L.; Hermsen, M. Adenocarcinomas nasosinusales tipo intestinal. Perfil inmunohistoquímico de 66 casos. Acta Otorrinolaringol. Española 2013, 64, 115-123. [CrossRef]

58. López, F.; Llorente, J.L.; Costales, M.; García-Inclán, C.; Perez-Escuredo, J.; Álvarez-Marcos, C.; Hermsen, M.; Suárez, C. Caracterización molecular de los carcinomas nasosinusales y sus implicaciones clínicas. Acta Otorrinolaringol. Española 2013, 64, 289-296. [CrossRef]

59. Poorten, V.V.; Jorissen, M. A Comprehensive Update on Intestinal- and Non-Intestinal-Type Adenocarcinomas. Advances in Oto-Rhino-Laryngol. 2020, 84, 137-153. [CrossRef]

60. Stelow, E.B.; Jo, V.Y.; Mills, S.E.; Carlson, D.L. A Histologic and Immunohistochemical Study Describing the Diversity of Tumors Classified as Sinonasal High-grade Nonintestinal Adenocarcinomas. Am. J. Surg. Pathol. 2011, 35, 971-980. [CrossRef]

61. Purgina, B.; Bastaki, J.M.; Duvvuri, U.; Seethala, R.R. A Subset of Sinonasal Non-Intestinal Type Adenocarcinomas are Truly Seromucinous Adenocarcinomas: A Morphologic and Immunophenotypic Assessment and Description of a Novel Pitfall. Head Neck Pathol. 2015, 9, 436-446. [CrossRef] [PubMed]

62. Leivo, I. Sinonasal Adenocarcinoma: Update on Classification, Immunophenotype and Molecular Features. Head Neck Pathol. 2016, 10, 68-74. [CrossRef] [PubMed]

63. Jo, V.Y.; Mills, S.E.; Stoler, M.H.; Stelow, E.B. Papillary Squamous Cell Carcinoma of the Head and Neck. Am. J. Surg. Pathol. 2009, 33, 1720-1724. [CrossRef] [PubMed]

64. Storck, K.; Hadi, U.M.; Simpson, R.; Ramer, M.; Brandwein-Gensler, M. Sinonasal Renal Cell-like Adenocarcinoma: A Report on Four Patients. Head Neck Pathol. 2008, 2, 75-80. [CrossRef] [PubMed]

65. Ereño, C.; Gaafar, A.; Garmendia, M.; Etxezarraga, C.; Bilbao, F.J.; López, J.I. Basaloid Squamous Cell Carcinoma of the Head and Neck. A Clinicopathological and Follow-Up Study of 40 Cases and Review of the Literature. Head Neck Pathol. 2008, 2, 83-91. [CrossRef]

66. Wiseman, S.M.; Popat, S.R.; Rigual, N.R.; Hicks, W.L., Jr.; Orner, J.B.; Wein, R.O.; McGary, C.T.; Loree, T.R. Adenoid cystic carcinoma of the paranasal sinuses or nasal cavity: A 40-year review of 35 cases. Ear Nose Throat J. 2002, 81, 510-514, 516-517. [CrossRef]

67. Perez, D.E.D.C.; Pires, F.R.; Lopes, M.A.; de Almeida, O.P.; Kowalski, L.P. Adenoid Cystic Carcinoma and Mucoepidermoid Carcinoma of the Maxillary Sinus: Report of a 44-Year Experience of 25 Cases From a Single Institution. J. Oral Maxillofac. Surg. 2006, 64, 1592-1597. [CrossRef]

68. Lupinetti, A.D.; Roberts, D.B.; Williams, M.D.; Kupferman, M.E.; Rosenthal, D.; Demonte, F.; El-Naggar, A.; Weber, R.S.; Hanna, E.Y. Sinonasal adenoid cystic carcinoma. Cancer 2007, 110, 2726-2731. [CrossRef]

69. Ahn, B.; Kim, E.; Oh, H.; Chae, Y.-S.; Kim, C.H.; Lee, Y.; Lee, J.H.; Lee, Y.J. Human Papillomavirus-Related Multiphenotypic Sinonasal Carcinoma with Late Recurrence. J. Pathol. Transl. Med. 2019, 53, 337-340. [CrossRef] 
70. Bishop, J.A.; Andreasen, S.; Hang, J.-F.; Bullock, M.J.; Chen, T.Y.; Franchi, A.; Garcia, J.J.; Gnepp, D.R.; Gomez-Fernandez, C.R.; Ihrler, S.; et al. HPV-related Multiphenotypic Sinonasal Carcinoma: An expanded series of 49 cases of the tumor formerly known as HPV-related carcinoma with adenoid cystic carcinoma-like features. Am. J. Surg. Pathol. 2017, 41, 1690-1701. [CrossRef]

71. Peraza, A.; Gómez, R.; Beltran, J.; Amarista, F. Mucoepidermoid carcinoma. An update and review of the literature. J. Stomatol. Oral Maxillofac. Surg. 2020, 121, 713-720. [CrossRef] [PubMed]

72. Shah, K.; Perez-Ordóñez, B. Neuroendocrine Neoplasms of the Sinonasal Tract: Neuroendocrine Carcinomas and Olfactory Neuroblastoma. Head Neck Pathol. 2016, 10, 85-94. [CrossRef] [PubMed]

73. Perez-Ordonez, B.; Caruana, S.M.; Huvos, A.G.; Shah, J.P. Small cell neuroendocrine carcinoma of the nasal cavity and paranasal sinuses. Hum. Pathol. 1998, 29, 826-832. [CrossRef]

74. Xu, B.; Chetty, R.; Perez-Ordoñez, B. Neuroendocrine Neoplasms of the Head and Neck: Some Suggestions for the New WHO Classification of Head and Neck Tumors. Head Neck Pathol. 2014, 8, 24-32. [CrossRef]

75. Weinreb, I.; Perez-Ordoñez, B. Non-Small Cell Neuroendocrine Carcinoma of the Sinonasal Tract and Nasopharynx. Report of 2 Cases and Review of the Literature. Head Neck Pathol. 2007, 1, 21-26. [CrossRef]

76. Tang, L.H.; Untch, B.R.; Reidy, D.L.; O’Reilly, E.M.; Dhall, D.; Jih, L.; Basturk, O.; Allen, P.J.; Klimstra, D.S. Well-Differentiated Neuroendocrine Tumors with a Morphologically Apparent High-Grade Component: A Pathway Distinct from Poorly Differentiated Neuroendocrine Carcinomas. Clin. Cancer Res. 2016, 22, 1011-1017. [CrossRef]

77. Czapiewski, P.; Kunc, M.; Haybaeck, J. Genetic and molecular alterations in olfactory neuroblastoma: Implications for pathogenesis, prognosis and treatment. Oncotarget 2016, 7, 52584-52596. [CrossRef]

78. Ben-Neriah, Y.; Karin, M. Inflammation meets cancer, with NF-kB as the matchmaker. Nat. Immunol. 2011, 12, 715-723. [CrossRef]

79. Määttä, J. Characterization of oak and birch dust-induced expression of cytokines and chemokines in mouse macro-phage RAW 264.7 cells. Toxicology 2005, 215, 25-36. [CrossRef]

80. Pérez-Escuredo, J.; Martínez, J.G.; Vivanco, B.; Marcos, C.Á.; Suárez, C.; Llorente, J.L.; Hermsen, M.A. Wood dust-related mutational profile of TP53 in intestinal-type sinonasal adenocarcinoma. Hum. Pathol. 2012, 43, 1894-1901. [CrossRef]

81. Perrone, F. TP53, p14ARF, p16INK4a and H-RAS gene molecular analysis in intestinal-type adenocarcinoma of the na-sal cavity and paranasal sinuses. Int. J. Cancer 2003, 105, 196-203. [CrossRef]

82. Díaz-Molina, J.P.; Llorente, J.L.; Vivanco, B.; Martínez-Camblor, P.; Fresno, M.F.; Pérez-Escuredo, J.; Álvarez-Marcos, C.; Hermsen, M.A. Wnt-pathway activation in intestinal-type sinonasal adenocarcinoma. Rhinol. J. 2011, 49, 593-599. [CrossRef]

83. Perez-Ordonez, B.; Huynh, N.N.; Berean, K.W.; Jordan, R.C.K. Expression of mismatch repair proteins, $\beta$-catenin, and E-cadherin in intestinaltype sinonasal adenocarcinoma. J. Clin. Pathol. 2005, 57, 1080-1083. [CrossRef]

84. Takahashi, Y.; Bell, D.; Agarwal, G.; Roberts, D.; Xie, T.-X.; El-Naggar, A.; Myers, J.N.; Hanna, E.Y. Comprehensive assessment of prognostic markers for sinonasal squamous cell carcinoma. Head Neck 2014, 36, 1094-1102. [CrossRef]

85. Takahiro, H.; Hidetaka, Y.; Rina, J.; Yui, N.; Ryuji, Y.; Kazuki, H.; Reiko, Y.; Azusa, S.; Kenichi, T.; Muneyuki, M.; et al. Clinicopathologic Significance of EGFR Mutation and HPV Infection in Si-nonasal Squamous Cell Carcinoma. Am. J. Surg. Pathol. 2021, 45, 108-118.

86. Dang, L.; Yen, K.; Attar, E.C. IDH mutations in cancer and progress toward development of targeted therapeutics. Ann. Oncol. 2016, 27, 599-608. [CrossRef]

87. Dunn, G.P.; Andronesi, O.C.; Cahill, D.P. From genomics to the clinic: Biological and translational insights of mutant IDH1/2 in glioma. Neurosurg Focus. 2013, 34, E2-E15. [CrossRef]

88. Blanch, J.L.; Ruiz, A.M.; Alos, L.; Traserra-Coderch, J.; Bernal-Sprekelsen, M. Treatment of 125 Sinonasal Tumors: Prognostic Factors, Outcome, and Follow-up. Otolaryngol. Neck Surg. 2004, 131, 973-976. [CrossRef]

89. Harbo, G.; Grau, C.; Bundgaard, T.; Overgaard, M.; Elbrønd, O.; Søgaard, H.; Overgaard, J. Cancer of the Nasal Cavity and Paranasal Sinuses:A Clinico-pathological Study of 277 Patients. Acta Oncol. 1997, 36, 45-50. [CrossRef] [PubMed]

90. Parsons, J.T.; Mendenhall, W.M.; Mancuso, A.A.; Cassisi, N.J.; Million, R.R. Malignant tumors of the nasal cavity and ethmoid and sphenoid sinuses. Int. J. Radiat. Oncol. 1988, 14, 11-22. [CrossRef]

91. Sjöstedt, S.; Karnov, K.; von Buchwald, C. Diagnostics and treatment of sinonasal cancer. Ugeskr. laeger 2018, 180, 30259840.

92. Sivalingam, J.; Sarawagi, R.; Raghuwanshi, S.; Yadav, P.K. Sinonasal Neoplasia - Clinicopathological Profile And Importance of Computed Tomography. J. Clin. Diagn. Res. 2015, 9, TC01-TC04. [CrossRef]

93. Westerveld, G.J.; Van Diest, P.J.; Van Nieuwkerk, E.B. Neuroendocrine carcinoma of the sphenoid sinus: A case report. Rhinol. J. 2001, 39, 52-54.

94. Oztürk, E.; Sağlam, O.; Sönmez, G.; Cüce, F.; Haholu, A. CT and MRI of an unusual intranasal mass: Pleomorphic adenoma. Diagn. Interv. Radiol. 2008, 14, 186-188. [PubMed]

95. Flavahan, P.W.; Keir, J.; Srinivasan, V. Neuroendocrine carcinoma of the ethmoid sinuses treated with radiotherapy alone. J. Laryngol. Otol. 2012, 126, 1066-1068. [CrossRef]

96. Wang, E.W.; Zanation, A.M.; Gardner, P.A.; Schwartz, T.H.; Eloy, J.A.; Adappa, N.D.; Bettag, M.; Bleier, B.S.; Cappabianca, P.; Carrau, R.L.; et al. ICAR: Endoscopic skull-base surgery. Int. Forum Allergy Rhinol. 2019, 9, S145-S365. [CrossRef]

97. Patel, S.H.; Wang, Z.; Wong, W.W.; Murad, M.H.; Buckey, C.R.; Mohammed, K.; Alahdab, F.; Altayar, O.; Nabhan, M.; Schild, S.E.; et al. Charged particle therapy versus photon therapy for paranasal sinus and nasal cavity malignant diseases: A systematic review and meta-analysis. Lancet Oncol. 2014, 15, 1027-1038. [CrossRef] 
98. Holliday, E.B.; Frank, S.J. Proton Radiation Therapy for Head and Neck Cancer: A Review of the Clinical Experience to Date. Int. J. Radiat. Oncol. 2014, 89, 292-302. [CrossRef] [PubMed]

99. Lefebvre, J.-L.; Chevalier, D.; Luboinski, B.; Kirkpatrick, A.; Collette, L.; Sahmoud, T. Larynx Preservation in Pyriform Sinus Cancer: Preliminary Results of a European Organization for Research and Treatment of Cancer Phase III Trial. EORTC Head and Neck Cancer Cooperative Group. J. Natl. Cancer Inst. 1996, 88, 890-899. [CrossRef] [PubMed]

100. Wolf, G.T.; Fisher, S.G.; Hong, W.K.; Hillman, R.; Spaulding, M.; Laramore, G.E.; Endicott, J.W.; McClatchey, K.; Henderson, W.G.; Department of Veterans Affairs Laryngeal Cancer Study Group. Induction Chemotherapy plus Radiation Compared with Surgery plus Radiation in Patients with Advanced Laryngeal Cancer. New Engl. J. Med. 1991, 324, 1685-1690. [CrossRef] [PubMed] 